\author{
Ye. V. Tukalenko', Ye. M. Prokhorova ${ }^{1}$, N. P. Atamanuk ${ }^{1}$, I. R. Dmitrieva ${ }^{1}$, I. I. Tubaltseva ${ }^{2}$, \\ I. P. Drozd ${ }^{3}$, A. I. Lypska ${ }^{3, *}$, V. V. Talko ${ }^{1}$ \\ ${ }^{1}$ National Research Center for Radiation Medicine, \\ National Academy of Medical Sciences of Ukraine, Kyiv, Ukraine \\ ${ }^{2}$ Taras Shevchenko National University of Kyiv, Kyiv, Ukraine \\ ${ }^{3}$ Institute for Nuclear Research, National Academy of Sciences of Ukraine, Kyiv, Ukraine \\ *Corresponding author: lypska@kinr.kiev.ua
}

\title{
NEUROBIOLOGICAL EFFECTS DUE TO INTRAUTERINE EXPOSURE OF RATS WITH ${ }^{131}$ I
}

The article studies the influence of prenatal exposure of rats with ${ }^{131} \mathrm{I}$ on their behavioral activity and anxiety using the open field test, an elevated raised cross-shaped maze, black and white and shuttle box. It is determined that prenatal exposure of rats with ${ }^{131} \mathrm{I}$ has led to increased research activity, but did not cause significant changes in the levels of animals' anxiety. There has been also an decrease in the number of conditioned reflexes and prolongation of the latent periods of reflex reactions, indicating that there is some suppression of CNS due to exposure conditions.

Keywords: rats; ${ }^{131} \mathrm{I}$, prenatal exposure, behavioral responses, anxiety.

\section{Introduction}

Sensitivity of the structures of the developing brain to ionizing radiation influence manifests itself through the complex set of functional, morphological, ultrastructural and metabolic disorders at all levels of organization. Indepth study of these issues is critical for predicting pathogenic effects from exposure to radiation. Human brain is the most radiation-sensitive structure in the prenatal period, especially at $8-15$ weeks of gestation (the period of rapid proliferation of neurons) that has their migration to places of their final placement in the cerebral cortex. During this period there is a significant risk of mental retardation. It has been widely researched that the risk of abnormal fetal development due to external gamma irradiation is the highest duringthe embryo organogenesis period $[1,2]$. The effects observed as a result of the incorporation of radionuclides, are similar to the effects of external radiation, but they are understudied. For example, increased frequency of leukemia has been observed in female mice after administration of ${ }^{32} \mathrm{P}(1.5-4.5 \mathrm{MBq} / \mathrm{animal})$ at the stage of organogenesis at $11-15$-day of pregnancy. There they got somewhat contradictory data on the blastogenic action of radionuclides which were evenly distributed in the body. Incorporation of tritium oxide (6.6 - $660 \mathrm{cGy})$ in female rats during pregnancy increased the frequency and the rate of breast cancer. However, introduction of ${ }^{137} \mathrm{Cs}$ in the numbers that form the absorbed dose in the body of 1.0 and $4.0 \mathrm{~Gy}$, did not affect the incidence and rate of tumor formation as compared to the control group. There is also data concerning the carcinogenic effect from ${ }^{90} \mathrm{Sr}$, administered to pregnant female rats at 18 days after conception, and ${ }^{239} \mathrm{Pu}$ after the incorporation phase of organogenesis (9 15 th day) and during the formation of a fetus (19th day) [3]. However, an open question remains concerning the influence of one the most dangerous dietary radionuclides, which was formed as a result of the Chornobyl accident, ${ }^{131} \mathrm{I}$, on the brain in the context of internal prenatal exposure.

The aim of our study was to investigate in the long-term period the influence of ${ }^{131} \mathrm{I}$ on the behavioral responses Wistar rats exposed in utero.

\section{Materials and methods}

The experimental studies conducted on 24 male Wistar rats (11 exposed in utero to ${ }^{131} \mathrm{I}$ and 13 were control - intact) which had been breeding in the vivarium of the Bogomolets Institute of Physiology, NAS of Ukraine. Introduction of an experimental model of the prenatal exposure of rats involved a single injection of pregnant females with the initial weight $200 \pm 15 \mathrm{~g}$ in the middle of the gestational period with the radioizotope ${ }^{131} \mathrm{I}$ with the $27.35 \mathrm{kBq}$ activity that formed the dose of 5.0 Gy on the thyroid gland. The animals were kept under standard vivarium conditions.

Kinetics of the ${ }^{131}$ I distribution in rats and dose calculations have been performed on the fetus at the Institute for Nuclear Research, NAS of Ukraine [4]. Methodolody of doses' calculations was based on the experimental results concerning the content of ${ }^{131} \mathrm{I}$ in the embryo and fetus at different stages of females' pregnancy and also on the already published sources on the dynamics of embryonic development of rats and on the formation and development of fetal thyroid gland [5]. 
The effect of prenatal exposure tothe ${ }^{131} \mathrm{I}$ on the behavioral aspects and anxiety of rats has been studied using an open field test, raised cross-shaped maze, black and white and shuttle cameras. Testing of animals was carried out once they reached the sixmonths age. Time of testing: from 5 to 8 p.m. Animal behavior was recorded using a Logitech webcam way so that to avoid the presence of the experimenter on the animals' behavior.

The study of rats' behavior in the open field. The test is used to evaluate spontaneous locomotor and research activity of rats. Installation for testing is a square chamber of $1 \mathrm{~m}$ wide and $1 \mathrm{~m}$ long, with the walls of $40 \mathrm{~cm}$ high. The floor of the chamber is a plastic sheet with a stamped grid on it that divides the chamber into equal size squares.

The researchers fixed the number of crossed peripheral and central squares, and the intersection of central squares was considered as an indicator of research activity. In addition, we have also recorded: the number of racks (as a measure of research activity), grooming (can be interpreted as a measure of comfort situation but also as an indicators of stress and high anxiety), the number of bowel movements and urination (as an indicator of autonomic behavior). Rats were placed one by one at the center of an open field and during 3 min we have recorded the behavioral activity of animals according to the above parameters.

Studying rats' behavior in the elevated crossshaped maze. Behavior of rats in this test is the integral result of three motivations combined: tentative research reflex, hole exploratory reflex (the reflex of darkness) and the fear of height.The intensity of each motivation has been determined by the specific conditions and is subject to change due to various factors.

Installation of "cross-elevated maze" consists of two crossing each other passways which are raised above the floor, one of which has a perimeter wall ("closed sleeves"), while others do not have such a wall ("open sleeves»). At the intersection of both pass ways there is a central platform without any wall which is the starting point during the test. The height of the elevation of the labyrinth above the floor is $80 \mathrm{~cm}$, the length of each sleeve is $45 \mathrm{~cm}$, their height and width is $10 \mathrm{~cm}$ each. Before the experiment the animal was transferred by the tail on the central platform of the labyrinth so that the animal was facing the open sleeve. After $5 \mathrm{~min}$ of testing the animal was returned to the cage. The floor of all passways at the end of each rat experimentwas thoroughly rubbed with wet wipes. We have recorded the following indicators during this experiment: the number and duration of entries to the open and closed passways of the maze, the number of upright postures, the number of looking down the open sleeves, the number of crossings of the central platform of the maze and the time spent on the platform, the overall time of the animal being still and finally the parameters of grooming (total duration of grooming and the frequency of grooming acts). It is generally assumed that reducing anxiety is reflected in the increased locomotion, especially in the number and duration of exits into the open arms of the maze. An important indicator of rats' behavior is the ratio of time spent in open sleevs to the time spent in closed ones. The less anxious the animal is, the higher is this ration.

Research of rats' behavior in black-and-white camera. Installation is a camera that has two sections:dark section which is $40 \mathrm{~cm}^{3}$, and the light one of the similar size. These sections are joint with each other by the hole $(10.5 \mathrm{~cm})$. The light section is illuminated by the lamp $(100 \mathrm{~W})$ and the other one is closed and light-proof. The dark section has an opaque ceiling, while the illuminated part serves for observations over the animal and its behavior via the webcam. The order of the study was as follows. The animal was placed into the dark compartment, which after that was connected with the lighted compartment. Within 3 minutes we recorded the behavior of the rat, and then returned the animal to the cage.

We have recorded the following indicators: time spent in the light and dark compartments, the number of looking through the hole between the compartments (which is the measure of situational anxiety), the number of entries into the illuminated compartment.

Studying the behavior of animals via shuttle box. Behavior of rats during this test is the integral result of motivations: tentative research activity and hole exploratory behavior (the reflex of darkness advantage), which has a lot of similarities with the test of raised cross-shaped maze.

In this study we have used the shuttle box assuming there is a possibility for using a single unconditioned stimulus (electric current supplied to the slatted floor) and two conventional (light bulbs and a speaker). This enabled us applying the developed by us methodology with one stimulis being the primary one and the second one as auxiliary, and the animal was supposed to differentiate them responding differently. If to avoid the electric shock, the animal was supposed to jump to safe compartment, in case of another stimulus -it was supposed to remain in the same compartment of the shuttle box (if the animal responded in the same way, it got the electric shock - thus, it was a wrong reaction). The sequence and frequency of the primary and secondary stimuli were randomized, as this was according to the appropriate computer 
software with which the experiment was carried out as wel as control and registration of all animals' behavior. From the overall number of the attempts (one test involved 100 cycles) each of the stimuli was used in $50 \%$ of the cases. Testing of the animals was carried out 10 times a week. Each new test of the same animal was performed under the changed stimuli: if in the firsttest the key conditional stimulus was light, and extra one was sound, in the next test it was on the opposite. This forced the animal to learn each time again. That is, we have not only studied the sustainability of the acquired behavior, but also the the process of learning. As it had been already shown by previous special studies, such a scheme for an experiment significantly increases the sensitivity of the method in detecting changes in behavioral responses in the event of impact from various stressors. Applying this method, we have investigated the conditioned reflex of active avoidance of electric shock.

We determined and analyzed the following parameters: a latent period of a conditioned response (time from beginning of the conditioned stimulus to animal's hiding into a secure compartment), the total number of conditioned reflexes of active avoidance, the average number of the conditioned reflexes in their series (one by one), the number of cross-signal reactions.

All these parameters lead us to better understanding of the state of the conditioned-reflex behavior of animals (their ability to study, the dynamics of this study, sustainability of acquired reactions, the rate of the conditioned reflexes' development).

\section{Results and Discussion}

In the open field test the control rats crossed, on average, $5.0 \pm 0.9$ of the central squares, and this figure for the exposed rats did not differ from the control group and was $7.1 \pm 1.8$ squares. Locomotor activity which was determined by the number of the peripheral crossed squares was also the same for the animals of the control and experimental groups and amounted to $60.4 \pm 4.6$ and $56.6 \pm 8.0$ squares respectively. At this, the number of animals entering the center of an open field was also on the same level in the control and exposed animals groups. The values were respectively $2.9 \pm 1.1$, and $2.6 \pm 0.6$. Another indicator of research activity - the number of upright postured also did not differ between two groups: the control rats showed $12.7 \pm 1.5$ upright postures, while for the exposed animals this figure was $14.2 \pm 1.5$. The number of bowel movements, which to some extent reflects the emotionally vegetative tension, in the control group was $2.4 \pm 0.5$ of bowels. And among the exposed animals it was not significantly different from the control group and was $2.7 \pm 0.6$ bowels. Thus, the results of testing in the open field did not find any significant difference between the control and the experimental groups of animals.

The test of the raised cross-shaped maze mostly did not reveal any significant differences between the indicators of both groups either. Thus, the total time spent in the open sleeves for the control group was $24.0[\min 7.1 ; \max 34.3] \mathrm{s}$, while the irradiated groupit was significantly higher and amounted to 32.0 [ $\min 10.2 ; \max 44.7] \mathrm{s}$. There were no detected differences in the length of stay in the closed sleeves of the maze between the control and irradiated animals (133.2 [min103.9; max149.9] $\mathrm{s}$ and 105.8 [min80.8; $\max 136.8$ ] s, respectively). Therefore, it seems logical that there no differences between the control group and the experimental group by the number of exits to open and closed sleeves of the maze, accordingly -2.1 [min $1 ; \max 3]$ and 3.7 [min2; $\max 5]$ for the control group, and $2.6[\min 1$; max4] and 4.4 [min4; $\max 5]$ for the experimental rats. In addition, the number of crossing the center did not differ between the two groupsand amounted to $4.9[\min 3 ; \max 7]$ for control rats and 5.7 [min4; $\max 7]$ for the irradiated animals. However, we have found a significant difference $(\mathrm{p}<.0 .001)$ in the research activity indicator - the number of upright postures for the control rats was $8.4[\min 5$; $\max 11]$ on the hind feet as compared to 15.5 [min12; max19] on the hind feet for the irradiated animals.

The indicators of grooming the animals demonstrated during the testing at the elevated maze was not significantly different for the control and experimental groups of animals. Thus, the number of grooming acts in the control group of animals was $1.8[\min 0 ; \max 4]$, and forthe irradiated rats it was $2.9[\min 1 ; \max 4]$.

Given that there are almost no differences in the test of the raised cross-shaped maze (except the indicator of upright postures), we can conclude that in utero exposure to ${ }^{131} \mathrm{I}$ led to a certain increase of research activity, but does not affect the anxiety of animals overall.

In the black-and-white test chamber we have found a certain difference in terms of anxiety between the groups. Thus, the number of looking out from the dark compartment and of the latent period of looking out is not statistically different between the groups, and for the control group they were 2 [min 1; $\max 7]$ and 10.4 [min0.75; $\max 20.8] \mathrm{s}$, respectively, and for theexperimental animals - 5 [min4; $\max 8]$ and 12.2 [min2.7; $\max 19.2] \mathrm{s}$. However, the significant difference was found between the animals of these groups in terms of the length of stay in the lit compartment, which for the 
control animals was $0[\min 0 ; \max 17.9] \mathrm{s}$, but for the irradiated animals it was significantly higher and amounted to 27.5 [min6; $\max 35] \sec (\mathrm{p}<0.05)$.

With the lack of significant differences in the number of looking out in the illuminated compartment $(0[\min 0 ; \max 1]$ for the control group and $1[\min 0 ; \max 2]$ for the experimental animals) we have found a statistical trend $(\mathrm{p}<0.08)$ regarding the difference in the indicator latent looking out into the lit compartment. That is, the control rats were proned for earlier looking out into the lit compartment, but they spent less time there as compared with the experimental animals. Also, we have found the reliable differences $(p<0.05)$ in the research activity indicator - the number of upright postures for the control rats was 0 [min0; $\max 2]$ as compared with 4 [min0; $\max 5]$ for the irradiated animals. Similar changes of this indicator were observed during the testing at elevated cross-formed maze, but not in the open field. Such averse test conditions have largely increased the level of research activity in the irradiated rats as compared with the control group. The indicators of grooming the animals demonstrated during the testing in the black-and-white camera were not significantly different between the groups.

Assessment of the cognitive status was conducted in this study using the shuttle box method. Before learning, the latent period of rats' looking out into the lit compartment from dark one was the same for the control and experimental groups and was respectively $36.1 \pm 14.4 \mathrm{~s}$ and $30.6 \pm 8.0 \mathrm{~s}$. This was determined by the results of two attempts of the test. After determining the baseline values of the latent looking out we have conducted theassociative learning by stimulating electrically by the stabilized current of $0.8 \mathrm{~mA}$ in the dark compartment during $15 \mathrm{~s}$. Reliability and direction of the impact of prenatal exposure on the behavior of rats were assessed using a variance-regression analysis (Table).

Regression analysis of the cumulative values of the conditioned reflex activity of Wistar rats that underwent in utero exposure to ${ }^{131} \mathrm{I}$ (the analysis of 162 values during 2 months of observations, 24 animals)

\begin{tabular}{|c|c|c|c|}
\hline Index & Factor & $\begin{array}{l}\text { Coefficients of level } \\
\text { of plural regression }\end{array}$ & $\mathrm{p}$ \\
\hline \multirow{3}{*}{$\begin{array}{l}\text { The total number of conditioned reflexes } \\
\text { of active avoidance }\end{array}$} & Constant & $\mathrm{a}_{0}=40.6$ & $<0.00001$ \\
\hline & Time (day) & $a_{1}=2.79$ & $<0.00001$ \\
\hline & Irradiation & $a_{2}=-62.6$ & $<0.00001$ \\
\hline \multirow{3}{*}{$\begin{array}{l}\text { The number of the conditioned reflexes } \\
\text { in their series (one by one) }\end{array}$} & Constant & $a_{0}=-21.7$ & $<0.1$ \\
\hline & Time (day) & $a_{1}=3.54$ & $<0.00001$ \\
\hline & Irradiation & $\mathrm{a}_{2}=65.5$ & $<0.00001$ \\
\hline \multirow{3}{*}{$\begin{array}{l}\text { The average number of the conditioned } \\
\text { reflexes }\end{array}$} & Constant & $\mathrm{a}_{0}=2.0$ & $<0.00001$ \\
\hline & Time (day) & $\mathrm{a}_{1}=0.18$ & $<0.00001$ \\
\hline & Irradiation & $a_{2}=-2.73$ & $<0.00001$ \\
\hline \multirow{3}{*}{$\begin{array}{l}\text { Latent phase of conditioned reflex } \\
\text { response }\end{array}$} & Constant & $\mathrm{a}_{0}=26.2$ & $<0.05$ \\
\hline & Time (day) & $\mathrm{a}_{1}=1.4$ & $<0.00001$ \\
\hline & Irradiation & $a_{2}=-25.6$ & $<0.05$ \\
\hline \multirow{3}{*}{ The number of cross-signal reactions } & Constant & $\mathrm{a}_{0}=26.2$ & $<0.05$ \\
\hline & Time (day) & $a_{1}=1.4$ & $<0.00001$ \\
\hline & Irradiation & $a_{2}=-25.6$ & $<0.05$ \\
\hline
\end{tabular}

Presented in Table data indicate the probable impact from prenatal exposure of rats to ${ }^{131} \mathrm{I}$ on the number of cross-signal reactions. Due to these conditions at the same time, we have also observed a decrease in the number of conditioned reflexes and prolongation of the latent period reflex responses. These changes should be interpreted as a sign of some suppression of the CNS, including reduced cognitive ability.

To study the dependence of behavioral reactions of rats on prenatal exposure, we used the equations of multiple linear regression. At the same time, for independent predictors were taken the following two factors: $\mathrm{T}$ - time from the beginning of testing (days): D - radiation dose of the thyroid of the fetus by radioactive iodine (Gy).
The following dependent variables were investigated, describing behavioral reactions: Naiz number of conditioned reflexes of active avoidance; Nfrst - number of attempts before the appearance of the first conditioned reflex; Navg - the average number of conditioned reflexes in the series; Tlat latent period of conditioned reflex reaction; $\mathrm{Nmsr}$ the number of inter-signal reactions. Thus, models of the effect of irradiation on the reaction of rats were described by the following equations:

$$
\begin{aligned}
& \text { Naiz }=a_{0}+a_{1} \cdot T+a_{2} \cdot D, \\
& \text { Nfrst }=a_{0}+a_{1} \cdot T+a_{2} \cdot D, \\
& \text { Navg }=a_{0}+a_{1} \cdot T+a_{2} \cdot D, \\
& \text { Tlat }=a_{0}+a_{1} \cdot T+a_{2} \cdot D, \\
& \text { Nmsr }=a_{0}+a_{1} \cdot T+a_{2} \cdot D .
\end{aligned}
$$


The results of calculations of regression significant changes in the level of animals' anxiety. coefficients are given in the Table.

\section{Conclusions}

1. The results of testing in the black-and-white camera and the data obtained in the open field tests and in the raised cross-formed labyrinth suggests that in utero exposure of the rats to ${ }^{131} \mathrm{I}$ leads to the increased research activity, but does not cause
2. According to the research on the behavioral responses of the animals in the shuttle box we have observed a clear negative effect from radiation: the decreased amount of the producedconditioned reflexes; prolonged becomes the latent period of conditioned-reflex reactions, while the speed of animals' learning and the stability of their acquired stereotypes is decreasing.

\section{REFERENCES}

1. ICRP Publication 49 Developmental effects of irradiation on the brain of the embryo and fetus. A report of a Task Group of Committee 1 of the Intern. Commission on Radiological Protection, 1986 (Oxford, New York, Toronto, Sydney, Frankfurt: Pergamon Press, 1986).

2. Radiation Risks to the Developing Nervous System. Proc. of Intern. Symp. Ed. by H. Kriegel, W. Schmahl, G.B. Gerber, F. E. Stieve (Stuttgart, New York: G. F. Verlag, 1986) 435 p.
3. Yu. I. Moskalev. Remote effects of ionizing radiation (Moscow: Medicine, 1991) 464 p. (Rus)

4. I.P. Drozd, A.I. Lypska, O.A. Sova. Simulation of ${ }^{131}$ I emergency emission. Processes of dose formation. Yaderna Fizyka ta Energetyka (Nucl. Phys. At. Energy) 16(2) (2015) 157 (Ukr)

5. I.P. Drozd et al. Patent No. 113045 UA. A method for determining the absorbed dose from the incorporation of ${ }^{131} \mathrm{I}$ into the thyroid gland of the laboratory rats fetus. Bull. No. 1 (2017). (Ukr)

\section{С. В. Тукаленко ${ }^{1}$, С. М. Прохорова ${ }^{1}$, Н. П. Атаманюк ${ }^{1}$, І. Р. Дмитрієва ${ }^{1}$, I. І. Тубальцева ${ }^{2}$ І. П. Дрозд ${ }^{3}$, А. І. Липська ${ }^{3 *}$, В. В. Талько ${ }^{1}$ \\ ${ }^{1}$ Національний науковий центрр радіаційної медицини НАМН Украӥни, Київ, Украӥна ${ }^{2}$ Київський національний університет імені Тараса Шевченка, Київ, Украйна \\ ${ }^{3}$ Інститут ядерних досліджень НАН Украӥни, Київ, Украӥна \\ *Відповідальний автор: lypska@kinr.kiev.ua}

\section{НЕЙРОБІОЛОГІЧНІ ЕФЕКТИ ВНУТРІШНЬОУТРОБНОГО ОПРОМІНЕННЯ ЩУРІВ ${ }^{131}$}

Вивчали вплив внутрішньоутробного опромінення щурів ${ }^{131} \mathrm{I}$ на поведінкову активність та тривожність із використанням тестів відкритого поля, піднятого хрестоподібного лабіринту, чорно-білої та човникової камер. Установлено, що внутрішньоутробне опромінення щурів ${ }^{131} \mathrm{I}$ призводило до підвищення рівня дослідницької активності, проте не викликало суттєвих змін рівня тривожності тварин. Спостерігалося зменшення кількості умовних рефлексів і подовження тривалості латентного періоду рефлекторних реакцій, що свідчить про певне пригнічення функції ЦНС за даних умов опромінення.

Ключові слова: щури, ${ }^{131} \mathrm{I}$, внутрішньоутробне опромінення, поведінкові реакції, тривожність.

\section{Е. В. Тукаленко ${ }^{1}$ Е. М. Прохорова ${ }^{1}$, Н. П. Атаманюк ${ }^{1}$ И. Р. Дмитриева ${ }^{1}$, И. И. Тубальцева $^{2}$, И. П. Дрозд ${ }^{3}$, А. И. Липская ${ }^{3, *}$, В. В. Талько ${ }^{1}$ \\ ${ }^{1}$ Национальный научный цеентр радиационной медицины НАМН Украины, Киев, Украина \\ ${ }^{2}$ Киевский национальный университет имени Тараса Шевченко, Киев, Украина \\ ${ }^{3}$ Институт ядерных исследований НАН Украины, Киев, Украина \\ *Ответственный автор: lypska@kinr.kiev.ua}

\section{НЕЙРОБИОЛОГИЧЕСКИЕ ЭФФЕКТЫ ВНУТРИУТРОБНОГО ОБЛУЧЕНИЯ КРЫС ${ }^{131}$}

Изучали влияние внутриутробного облучения крыс ${ }^{131}$ I на поведенческую активность и тревожность с использованием тестов открытого поля, приподнятого крестообразного лабиринта, черно-белой и челночной камер. Установлено, что внутриутробное облучение крыс ${ }^{131} \mathrm{I}$ приводило к повышению уровня исследовательской активности, однако не вызывало существенных изменений уровня тревожности животных. Наблюдалось уменьшение количества условных рефлексов и длительности латентного периода рефлекторных реакций, что свидетельствует о некотором угнетении функции ЦНС в данных условиях облучения.

Ключевые слова: крысы, ${ }^{131} \mathrm{I}$, внутриутробное облучение, поведенческие реакции, тревожность. 